\title{
Fatty acid and phenolic profiles of almond grown in Serbia
} \author{
Dragana Č́ Dabić Zagorac ${ }^{\mathrm{e}}$, Maja M. Natić ${ }^{\mathrm{d}}$ \\ ${ }^{a}$ Institute for Science Application in Agriculture, Blvd. despota Stefana 68b, 11000 Belgrade, Serbia \\ ${ }^{\mathrm{b}}$ Faculty of Agriculture, University of Belgrade, Nemanjina 6, Zemun, 11080 Belgrade, Serbia \\ ${ }^{\mathrm{c}}$ Center for Food Analysis, Zmaja od Noćaja 11, 11000 Belgrade, Serbia \\ d Faculty of Chemistry, University of Belgrade, P.O. Box 51, 11158 Belgrade, Serbia \\ e Innovation Centre, Faculty of Chemistry Ltd., Studentski trg 12-16, 11000 Belgrade, Serbia
}

Slavica D. Čolić ${ }^{a}, *$, Milica M. Fotirić Akšíc ${ }^{b}$, Kristina B. Lazarevićc ${ }^{c}$ Gordan N. Zec ${ }^{b}$, Uroš M. Gašić ${ }^{d}$

\section{A R T I C L E I N F O}

\section{Article history:}

Received 24 September 2016

Received in revised form 27 April 2017

Accepted 1 May 2017

Available online 3 May 2017

\section{Keywords:}

Prunus dulcis

Genetic resources

Fatty acids

Polyphenols

PCA

Antioxidant activity

\begin{abstract}
A B S T R A C T
Almond production is not typical for Serbia however the existence of natural populations and unexpectedly suitable agro-climatic conditions initiated this kind of study. Total oil content and concentrations of the fatty acids, total phenolic content and radical-scavenging activity were determined in the kernel oil of 20 local almond selections originating from North Serbia and cultivars 'Marcona', 'Texas' and 'Troito'. Sixteen fatty acids were identified and quantified, with the most abundant being oleic acid and linoleic acid. Nine phenolic acids and nineteen flavonoids were quantified using UHPLC-DAD MS/MS. The predominant polyphenol was catechin, followed by chlorogenic acid and naringenin. Based on oleic acid/ linoleic acid ratio, levels of unsaturated fatty acids and specific polyphenols, some selections were chosen for growing and could also be recommended for breeding programs. Our investigation demonstrated that this region could be a suitable for growing almonds with chemical compositions competitive with standard cultivars.
\end{abstract}

(c) 2017 Elsevier Ltd. All rights reserved.

\section{Introduction}

Almond, Brazil nut, cashew, chestnut, heartnut, hazelnut, macadamia, peanut, pecan, pine nut, pistachio and walnut, one name 'nuts', are nutrient dense foods. In the last 20 years, extensive research has been carried out on the potential bioactive and health-promoting components of nuts (Alasalvar, Shahidi, \& Amaral, 2009; Miraliakbari \& Shahidi, 2008). Nuts are now considered as an important component of a healthy diet because they contain essential micronutrients like tocopherols (Kornsteiner, Wagner, \& Elmadfa, 2006), minerals (Özcan, Ünver, Erkan, \& Arslan, 2011), dietary fiber (Salas-Salvadó, Bulló, Pérez-Heras, \& Ros, 2006), phytosterols (Blomhoff, Carlsen, Andersen, \& Jacobs, 2006) and other phytochemicals with potential bioactivity. In human supplementation studies nuts have been shown to improve the lipid profile, increase endothelial function and reduce inflammation, all without causing weight gain (Vinson \& Cai, 2012). These qualities make nuts a nutritious healthy snack and can be used as ingredient in food formulation.

\footnotetext{
* Corresponding author.

E-mail address: slavicacol@yahoo.com (S.D. Čolić).
}

Almonds (Prunus dulcis (Mill.) D.A. Webb) are among the most popular edible nuts, typically used as snack foods or as ingredients in a variety of processed foods, especially in bakery and confectionery products. Although almonds contain high amounts of fat, the lipid fraction does not contribute to cholesterol formation in humans, due to high level of unsaturated (monounsaturated and polyunsaturated) fatty acids (Askin, Balta, Twekinas, Kazankaya, \& Balta, 2007; Beyhan, Aktas, Yilmaz, Simsek, \& Gerçekçioğlu, 2011). Generally, the most important unsaturated fatty acids found in almond are oleic acid and linoleic acid (about 90\%), while saturated fatty acids are low in content $(<10 \%)$ (Yada, Lapsley, \& Huang, 2011). Besides proteins and fats, almonds contain sugars, mainly fructose and sucrose (Balta, Battal, Balta, \& Yoruk, 2009), vitamins (Segura, Casimiro, Lizarraga, \& Ros, 2006) and minerals (Özcan et al., 2011).

Several investigations on almond seeds and skin extracts revealed the presence of various phenolics compounds, well known to possess antioxidant potential. Vanillic acid, caffeic acid, p-coumaric acid, ferulic acid, quercetin, kaempferol, isorhamnetin, delphinidin and procyanidins B2 and B3 were determined in almond seed extract (Amarowicz, Troszynska, \& Shahidi, 2005). A total of 33 compounds corresponding to flavanols, flavonols, dihydroflavonols and flavanones, and other non-flavonoid compounds 
were identified by Monagas, Garrido, Lebrón-Aguilar, Bartolome, and Gómez-Cordovés (2007) in almond skin. According to Wijeratne, Amarowicz, and Shahidi (2006), almond skin, which contains ten times more polyphenols than the kernel, was characterized with isorhamnetin rutinoside, isorhamnetin glucoside, kaempferol rutinoside and kaempferol glucoside. Further, Bolling, Dolnikowski, and Blumberg (2009) detected catechins, as well as flavonoids such as naringenin, quercetin and kaempferol, predominantly as glucosides or rutinosides. As for the stilbenes, piceid (a derivative of resveratrol) was also reported in almond skin (Xie \& Bolling, 2014).

When incorporated in the diet, almonds positively affect cardiovascular and coronary heart diseases (Blomhoff et al., 2006; Wijeratne et al., 2006). As consumers become more interested in ensuring a healthy life style, the nutritional identification of almond genetic resources is important (Askin et al., 2007). For this reason, CITA (Agrifood Research and Technology Centre of Aragon, Spain) has incorporated chemical quality criteria as an objective in its almond breeding program (Socias i Company, Alonso, Kodad \& Gradziel, 2012). Therefore, selection of parents for low linoleic acid and high oil content might be undertaken in a breeding program for increased kernel quality (Kodad et al., 2014).

As all these investigations were done in countries with long traditions in almond production, the comparison of Serbian almond selections with cultivars grown worldwide would be worthwhile. Therefore, the first objective of the report herein was to monitor fatty acids and phenolic compositions of 20 Prunus dulcis selections from North Serbia and their comparison with the cultivars 'Marcona', 'Texas' and 'Troito'. Special attention was given to the composition of polyphenols, as well as to the possibility of establishing chemical compounds helpful for almond characterization and as selection criteria for almond quality evaluation. The final aim was to use multivariate statistics to identify the most promising genotypes based on specific components which could differentiate them. Such investigation enabled the selection of parents for further breeding programs in Serbia which could also be implemented in similar agro-ecological conditions.

\section{Materials and methods}

\subsection{Almond samples}

Twenty almond selections were chosen from the large spontaneous population of almonds in North Serbia, called Slankamen Hill, based on phenotypic diversity (Čolić, Rakonjac, Zec, Nikolić, \& Fotirić Akšić, 2012) and isoenzyme polymorphism (Čolić, Milatović, Nikolić, \& Zec, 2010). The orchard was planted at the Experimental Station of Institute PKB Agroekonomik, near Belgrade. It included 20 selections together with three cultivars Marcona (origin - Spain), Troito (origin - Italy) and Texas (origin - USA). Planting distance was $4 \times 3 \mathrm{~m}$. The orchard was under a non-irrigated regime. All necessary agro-technical measurements, as well as pest management were done in the orchard during the experimental period. The study location has a continental climate with hot and dry summers (maximum temperature up to $40^{\circ} \mathrm{C}$ ) and cold winters (minimum around $-20^{\circ} \mathrm{C}$ ). Average precipitation is $700 \mathrm{~mm} / \mathrm{y}$.

Each sample was represented by three trees, trained as an open vase. Selections/cultivars were harvested during two consecutive years, 2014 and 2015, at full maturity (hulls fully desiccated and opened along the suture). Harvest time for selections/cultivars was expressed as the number of days before or after Troito full maturity. Kernel color intensity, shell softness, and kernel taste were described on the basis of the International almond descriptor (Gülcan, 1985). Selection/cultivar traits are shown in Table 1.
For biochemical analyses, samples of 30 fruits per selection/cultivar were randomly harvested from cardinally oriented branches with different directions around the canopy. Seeds in endocarps were kept in paper bags in the dark until chemical analysis. Prior to analysis, the endocarp was broken and the seed was pulled out, without extra drying.

\subsection{Chemicals}

Standards of phenolic compounds used for UHPLC MS/MS analysis (protocatechuic acid, p-hydroxybenzoic acid, ellagic acid, vanillic acid, aesculin, chlorogenic acid, aesculetin, caffeic acid, $p$ coumaric acid, ferulic acid, sinapic acid, coniferyl aldehyde, phlorizin, phloretin, resveratrol, catechin, rutin, hyperoside, cynaroside, naringin, astragalin, luteolin, apigenin, naringenin, kaempferol, chrysin, pinocembrin, galangin) and Trolox were purchased from Sigma-Aldrich (Steinheim, Germany). Methanol, acetonitrile (both HPLC grade), formic acid, ethyl acetate, and Folin-Ciocalteu reagent were purchased from Merck (Darmstadt, Germany), while 2,2diphenyl-1-picrylhydrazyl radical (DPPH) was purchased from Fluka AG (Buch, Switzerland). Standard solutions and dilutions were prepared using ultrapure water (TKA Germany MicroPure water purification system, $0.055 \mu \mathrm{S} / \mathrm{cm}$ ). All other reagents were of analytical grade. The standard for fatty acid methyl esters determination used for GC-FID analysis was purchased from Restek (37 components Food Industry FAME Mix, RESTEK, lot: \#23889).

\subsection{Oil extraction and fatty acid methyl esters determination}

Forty grams of each sample of almond kernels, with brown skin, was ground until uniform flour (approximately $200 \mu \mathrm{m}$ particle size) was obtained. Crude oil was extracted from ground almond kernels using the Soxhlet extraction method (AOAC 920.39C). About $5 \mathrm{~g}$ of each sample was extracted in a Soxhlet apparatus, using $200 \mathrm{~mL}$ of petroleum ether (boiling range $40-60^{\circ} \mathrm{C}$ ) for $8 \mathrm{~h}$. At the end of the extraction period, the residual solvent was removed under a stream of nitrogen, and the extracted oil was stored at $-18^{\circ} \mathrm{C}$ under nitrogen until further analysis.

Fatty acid methyl esters (FAME) were prepared using transmethylation under alkaline conditions, following ISO 12966$2: 2012$. In a $10 \mathrm{~mL}$ screw-top test tube approximately $0.1 \mathrm{~g}$ of the extracted oil was weighed and dissolved in $2 \mathrm{~mL}$-hexane. After the addition of $1 \mathrm{~mL}$ of $2 \mathrm{~mol} / \mathrm{l}$ methanolic potassium hydroxide solution, the tube was vortexed for $2 \mathrm{~min}$ at room temperature, and centrifuged at $4000 \mathrm{rpm}$ for $5 \mathrm{~min}$. After $2 \mathrm{~min}, 2 \mathrm{~mL}$ of sodium chloride solution ( $40 \mathrm{~g}$ of sodium chloride in $100 \mathrm{~mL}$ of water) was added and the tube shaken briefly. The solution was neutralized by adding $1 \mathrm{~g}$ of sodium hydrogen sulfate monohydrate. After the salt had settled, $1 \mathrm{~mL}$ of the upper phase was transferred to a $2 \mathrm{~mL}$ vial for FAME analysis.

Fatty acid methyl esters were analysed by gas chromatography, using a GC DANI 1000 DPC, DANI Instrument SpaA, Italy, with flame ionization detection (FID). A fused-silica capillary column type Rtx-2330, Restec (phase: highly polar phase; biscyanopropyl cyanopropylphenyl polysiloxane, $0.25 \mathrm{~mm}$; column: $60 \mathrm{~m} \times 0.25 \mathrm{~mm}$ ) was used. The flow rate of nitrogen carrier gas was $1.2 \mathrm{~mL} / \mathrm{min}$. Injector and detector temperatures were $250^{\circ} \mathrm{C}$ and $300^{\circ} \mathrm{C}$, respectively. The oven temperature was programmed to maintain a temperature of $100^{\circ} \mathrm{C}$ for $4 \mathrm{~min}$, then to rise to $240{ }^{\circ} \mathrm{C}$ at a rate of $3{ }^{\circ} \mathrm{C} / \mathrm{min}$ and to maintain that temperature for $10 \mathrm{~min}$. The sample injection volume was $1 \mu \mathrm{l}$. Total run time for one cycle was 60 min. Fatty acid identifications were based on retention times by comparing with those of the standard FAME mixture. Quantification of individual fatty acids was based on the peak area obtained, without any corrections (EN ISO 5508:1995). Fatty acid analysis was performed in duplicate for single samples, 
Table 1

Almond samples and their characteristics.

\begin{tabular}{|c|c|c|c|c|c|}
\hline Genotype & Pedigree (cultivar/selection) & Harvest time & Kernel color intensity & Softness of shell & Kernel taste \\
\hline $1 / 03$ & Selection & -11 & Intermediate & Hard & Sweet \\
\hline $3 / 03$ & Selection & -5 & Dark & Soft & Sweet \\
\hline $4 / 03$ & Selection & -7 & Intermediate & Hard & Sweet \\
\hline $10 / 03$ & Selection & -7 & Intermediate & Hard & Intermediate \\
\hline $11 / 03$ & Selection & -11 & Intermediate & Hard & Sweet \\
\hline $12 / 03$ & Selection & -13 & Intermediate & Hard & Sweet \\
\hline $13 / 03$ & Selection & -11 & Intermediate & Hard & Sweet \\
\hline $14 / 03$ & Selection & -13 & Extremely light & Hard & Sweet \\
\hline $15 / 03$ & Selection & -13 & Intermediate & Hard & Sweet \\
\hline $16 / 03$ & Selection & -5 & Dark & Hard & Sweet \\
\hline $18 / 03$ & Selection & -7 & Light & Hard & Intermediate \\
\hline $19 / 03$ & Selection & -5 & Dark & Extremely hard & Sweet \\
\hline $23 / 03$ & Selection & -15 & Intermediate & Hard & Sweet \\
\hline $24 / 03$ & Selection & -15 & Dark & Hard & Intermediate \\
\hline $25 / 03$ & Selection & -13 & Light & Hard & Intermediate \\
\hline $27 / 03$ & Selection & -11 & Dark & Extremely hard & Sweet \\
\hline $28 / 03$ & Selection & -11 & Intermediate & Hard & Sweet \\
\hline $1 / 05$ & Selection & -7 & Intermediate & Hard & Intermediate \\
\hline ZD 1 & Selection & -11 & Dark & Intermediate & Sweet \\
\hline ZD 2 & Selection & -3 & Dark & Hard & Sweet \\
\hline Marcona & Cultivar & -5 & Intermediate & Hard & Sweet \\
\hline Troito & Cultivar & 0 & Intermediate & Hard & Sweet \\
\hline Texas & Cultivar & +3 & Dark & Intermediate & Intermediate \\
\hline
\end{tabular}

and average values were reported. The GC method for determining fatty acid methyl esters was validated following recommendations of the EURACHEM guide (Magnusson \& Ornemark, 2014) The average relative standard deviation (RSD) of repeatability for minor components (components present at less than $1 \%$ ) was $5 \%$, while the average RSD for the components present in percentages greater than $1 \%$ was $2-3 \%$.

\subsection{Extraction of polyphenols}

A $10 \mathrm{~g}$ of ground almond kernels (particle size approximately $200 \mu \mathrm{m}$ ), in triplicate, was defatted in a $150 \mathrm{~mL}$ beaker by adding $50 \mathrm{~mL}$ hexane. The solution was stirred in an ultrasonic bath for $30 \mathrm{~min}$ at room temperature. After filtration through Whatman No. 4 filter paper, the defatted almond residue was then extracted with $50 \mathrm{~mL}$ methanol/water $(70: 30, \mathrm{v} / \mathrm{v})$ in an ultrasonic bath for $30 \mathrm{~min}$ at $40^{\circ} \mathrm{C}$. The extraction was repeated three times (Arráez-Román, Fu, Sawalha, Segura-Carretero, \& Fernández-Gutiér rez, 2010). After filtration, all fractions were collected and concentrated to dryness by rotary evaporation under reduced pressure at $40{ }^{\circ} \mathrm{C}$. The residue was suspended in $70 \%$ methanol to $50 \mathrm{~mL}$ and this solution was used for further analysis.

\subsection{Determination of total phenolic contents (TPC)}

The content of total phenolics in almond extracts was determined colorimetrically by the Folin-Ciocalteu method with some modification (Pavlović et al., 2013). The absorbance of the samples was detected at $765 \mathrm{~nm}$ using a GBC Cintra 6 UV-Visible spectrophotometer. The content of total phenolics in the extract was determined using gallic acid as a standard at concentrations of 20-100 $\mathrm{mg} \mathrm{L}^{-1}$. Total extracted phenolics were expressed as $\mathrm{mg}$ gallic acid equivalent (GAE) per $\mathrm{kg}$ fresh weight (mg GAE/kg FW).

\subsection{Determination of the radical scavenging activity (RSA)}

Radical scavenging activity of the almond extracts was measured by 1,1-diphenyl-2-picrylhydrazyl (DPPH) radical according to a slightly modified literature method of Pavlovic et al. (2013). The decrease in absorbance was measured at $515 \mathrm{~nm}$ using a UV-Vis spectrophotometer to determine the concentration of
DPPH' remaining. Results were calculated using a Trolox standard curve $\left(100-800 \mu \mathrm{mol} \mathrm{L}^{-1}\right)$ and expressed in mmol of Trolox equivalents per $\mathrm{kg}$ of fresh sample $\left(\mathrm{mmol} \mathrm{TE} \mathrm{kg}^{-1} \mathrm{FW}\right)$. The reaction was carried out in triplicate and the results were reported as mean values.

\subsection{Determination of polyphenolics (UHPLC-DAD MS/MS)}

Separation and quantification of phenolic compounds were performed on a Dionex Ultimate 3000 UHPLC system equipped with a diode array detector (DAD) and TSQ Quantum Access Max triple quadrupole mass spectrometer (Thermo Fisher Scientific, Bremen, Germany), according to the slightly modified method already described by Natic et al. (2015). The elution was performed at $40{ }^{\circ} \mathrm{C}$ on a Syncronis $\mathrm{C} 18$ column $(100 \times 2.1 \mathrm{~mm}, 1.7 \mu \mathrm{m})$ from ThermoFisher Scientific. The mobile phase consisted of (A) $0.5 \%$ aqueous acetic acid solution and (B) acetonitrile MS grade, which were applied in the following gradient program: $5 \% \mathrm{~B}$ in the first minute, $5-95 \%$ B from 1.0 to $16.0 \mathrm{~min}$, from $95 \%$ to $5 \%$ B for 16.0-16.2 min, and 5\% B until the 20th min. The flow rate was set to $0.3 \mathrm{~mL} \mathrm{~min}{ }^{-1}$ and the detection wavelengths to 254 and $280 \mathrm{~nm}$. The injection volume was $5 \mu \mathrm{L}$.

A TSQ Quantum Access Max Triple-Quadrupole Mass Spectrometer equipped with a heated electrospray ionization (HESI) source was used with the vaporizer temperature kept at $200^{\circ} \mathrm{C}$, and the ion source settings as follows: spray voltage $5 \mathrm{kV}$, sheet gas $\left(\mathrm{N}_{2}\right)$ pressure $40 \mathrm{AU}$, ion sweep gas $\left(\mathrm{N}_{2}\right)$ pressure $1 \mathrm{AU}$ and auxiliary gas $\left(\mathrm{N}_{2}\right)$ pressure $8 \mathrm{AU}$, capillary temperature $300{ }^{\circ} \mathrm{C}$, and skimmer offset $0 \mathrm{~V}$. The mass spectrometry data were acquired in negative ion mode, in the $m / z$ range from 100 to 1000 . Multiple mass spectrometric scanning modes, including full scanning (FS), and product ion scanning (PIS), were conducted for qualitative analysis of the targeted compounds. The collision-induced fragmentation experiments were performed using argon as the collision gas, and the collision energy was varied depending on the compound. The time-selected reaction monitoring (tSRM) experiments for quantitative analysis were performed using two $\mathrm{MS}^{2}$ fragments for each compound that were previously defined as dominant in the PIS experiments (Natić et al., 2015). Quantification was done using available phenolic standards. Table S1 presents the list of quantified phenolics in almond samples in negative ionization 
mode with mean expected retention times $\left(t_{R}\right.$, min), mass of parent ions $(\mathrm{m} / \mathrm{z})$, masses of product ions $(\mathrm{m} / \mathrm{z})$ with specified collision energies $(\mathrm{eV})$, correlation coefficients, limits of detection (LOD) and quantification (LOQ), as determined using UHPLC-DAD MS/ MS analysis. The limits of detection (LOD) and quantification (LOQ) were calculated using standard deviations (SD) of the responses and the slopes of the calibration curves (S) according to the formulas: $\mathrm{LOD}=3(\mathrm{SD} / \mathrm{S})$ and $\mathrm{LOQ}=10(\mathrm{SD} / \mathrm{S})$. Standard deviations and slopes were obtained from the calibration curves created in MS Excel.

\subsection{Statistical analysis}

Data for all measurements were expressed as the mean values and Tukey's test was used to detect significant differences $(p \leq 0.05)$ between these values. Principal component analysis (PCA) was carried out by PLS ToolBox, v.6.2.1, for MATLAB 7.12.0 (R2011a). All data were auto scaled prior to multivariate analysis. PCA was carried out using a singular value decomposition algorithm and a 0.95 confidence level for $\mathrm{Q}$ and $\mathrm{T} 2$ Hotelling limits for outliers.

\section{Results and discussion}

\subsection{Oil and fatty acids determination}

Oil content in the almond samples and fatty acid composition of the oil are given in Table 2. Generally, our results indicated a high variability among the selections and cultivars in total oil content and fatty acids composition. Considerable variation was established in total oil contents, the highest oil content being found in selection 3/03 (62.86\%), while the lowest was obtained in selection $10 / 03(36.30 \%)$. The range in total oil content in this study was similar to the variability reported in the study of Kodad and Socias i Company (2008). Contents were slightly higher than those obtained by Askin et al. (2007), who found an oil content range from $25.2 \%$ to $60.8 \%$ for almond genotypes selected from Elazig province in Turkey and Özcan et al. (2011), who established an oil range from $48.8 \%$ to $55.7 \%$ for five commercial varieties. Oil content in Marcona was slightly lower than those reported by Kodad and Socias i Company (2008), which could be associated with different agroecological growing conditions.

As for fatty acids, sixteen of them were identified in our oil extracts (Table 2). This was fewer than the number of fatty acids found by Beyhan et al. (2011), who studied four commercial and five other almond genotypes from Tokat province and the Aegean region of Turkey. These differences in the numbers of fatty acids could be explained by the different genotypes analyzed, as previously determined by Kodad et al. (2014), and ecological conditions (Kodad \& Socias i Company, 2008).

Our study indicated four fatty acids: oleic, linoleic, palmitic and stearic acids, in decreasing order (Table 2) and in the majority of almond samples they represent over $99 \%$ of the total fatty acid content. Regarding the total fatty acid content in the oil, unsaturated acids - oleic acid and linoleic acid averagely amounted 69.86\% and $21.83 \%$, respectively, while saturated acids palmitic acid and stearic acid amounted for $5.48 \%$ and $1.90 \%$, respectively. This was in accordance with previous results of Beyhan et al. (2011), Özcan et al. (2011) and Kodad et al. (2014). In a study of the fatty acid composition of almond samples from different regions Zhu, Wilkinson, and Wirthensohn (2015) also reported that oleic acid and linoleic acid were found to be the most abundant, Oleic acid in our study ranged from 63.14 (14/03) to $77.37 \%$ (16/03), linoleic acid from $15.57(16 / 03)$ to $28.69 \%$ (14/03), palmitic acid from 4.68 $(1 / 05)$ to $6.48 \%(13 / 03)$ and stearic acid from $1.45(16 / 03)$ to $2.56 \%$
(Troito). Selections 16/03, 24/03, 1/05 and ZD1 showed higher contents of oleic acid, varied from $74.61 \%$ to $77.37 \%$, compared with Texas, having highest level of oleic acid among standard cultivars (74.59\%). The quantity of linoleic acid in nine samples $(1 / 03$, $3 / 03,10 / 03,12 / 03,13 / 03,14 / 03,15 / 03,19 / 03$ and 27/03) was above of Troito (22.63\%). Palmitic acid was generally higher in the cultivars (except 1/03,4/03,13/03 and 19/03), while the level of stearic acid in all genotypes, Marcona and Texas was less than in Troito (2.56\%).

Wider variation of oleic acid (50.41-81.2\%), palmitic acid (5.46$15.8 \%$ ) and linoleic acid (6.21-33.1\%) in almond genotypes selected from Elazig province (Turkey), reported by Askin et al. (2007), are probably a consequence of a different genotype and agroecological conditions (Kornsteiner et al., 2006; Kodad \& Socias i Company, 2008). Comparing linoleic acid levels in Spanish, Mediterranean, Californian and Australian almonds, Zhu et al. (2015) noticed that the regions producing almonds with lower linoleic acid were not irrigated, whereas Californian and Australian regions routinely apply irrigation to their orchards. Therefore, restriction of irrigation could be a reason for similarity of linoleic acid percentages in this study with Spanish and Mediterranean almonds. According to Kodad et al. (2014), oil content in almonds, and composition of oil, depends primarily on the genotype, but also on the environmental conditions.

Oleic/linoleic acid ratio ( $\mathrm{O} / \mathrm{L}$ rate) is used in determining the quality of the kernel due to its preventive effect on lipid oxidation (Zacheo, Cappello, Gallo, Santino, \& Cappello, 2000). Kodad and Socias i Company (2008) showed that it can be used to differentiate genotypes, because it does not change over the years. They also stressed the importance of a high oleic acid percentage to increase the resistance of almond kernels to oxidation during processing, storage and transport. The results presented in Table 2 showed the highest $\mathrm{O} / \mathrm{L}$ ratio in $16 / 03$ (4.97). Seven selections in total (16/03, ZD1, 24/03, 1/05, 23/03, 25/03 and 28/03) also showed higher value of the $\mathrm{O} / \mathrm{L}$ ratio compared with 'Marcona' (3.47), which is commonly used as a reference for oil stability. Therefore, these selections are potentially relevant for breeding programs.

Palmitoleic acid, heptadecanoic acid, cis-10-heptadecenoic acid, arachidic acid, linolenic acid and eicosenoic acid were present in all samples in very small amounts $(<0.5 \%)$. Tricosanoic acid was quantified in 20 samples, myristic acid in 18, behenic acid in 17 and pentadecanoic acid in 11 samples. Trace amounts of docosadienoic acid (omega-6), and lignoceric acids were found only in sample $3 / 03$. This could be explained by the softness of the shell, as selection 3/03 was the only almond in this study characterized by a soft shell. Mazinani, Hossein, Rad, and Khaneghah (2012) also detected lignoceric acid in an almond sample from Karaj, in ten-fold higher quantity than in our study, but shell softness was not reported in the study.

\subsection{Determination of TPC, RSA and polyphenol composition}

Generally, most of the antioxidants in nuts are located in the pellicle or outer soft shell (Milbury, Chen, C. Y. \& Dolnikowski, 2006). When nuts are peeled or roasted the antioxidant activity considerably reduces (Barreira, Ferreira, Oliveira, \& Pereira, 2008). Therefore, unpeeled raw almond kernels were investigated herein. Our results indicated high variability among the genotypes as each of the 23 almond samples was characterized by a unique phenolic profile. Total phenolic contents, radical-scavenging activity and phenolic profile of 23 almond samples are listed in Table 3. Differences in TPC concentrations were found to be higher amongst selections than amongst the cultivars. The highest TPC concentration was recorded in selection $18 / 03$ (1.39 mg GAE/g), and lowest in Marcona $(0.20 \mathrm{mg} \mathrm{GAE} / \mathrm{g})$. Those concentrations are much higher when compared with the results of Kiat, Siang, Madhavan, 
Table 2

Oil content in almond samples and fatty acids composition of oil (average 2014-2015).

\begin{tabular}{|c|c|c|c|c|c|c|c|c|c|c|c|c|c|c|c|c|c|c|c|c|c|c|c|c|}
\hline $\mathrm{N}^{\mathrm{o}^{*}}$ & & $1 / 03$ & $3 / 03$ & $4 / 03$ & $10 / 03$ & $11 / 03$ & $12 / 03$ & $13 / 03$ & $14 / 03$ & $15 / 03$ & $16 / 03$ & $18 / 03$ & $19 / 03$ & $23 / 03$ & $24 / 03$ & $25 / 03$ & $27 / 03$ & $28 / 03$ & $1 / 05$ & ZD 1 & ZD 2 & Marcona & Troito & Texas \\
\hline 1 & $\begin{array}{l}\text { Oil content (\%) } \\
\text { Fatty acid composition (\% }\end{array}$ & $\begin{array}{l}51.90^{\mathrm{f}^{* *}} \\
\%)\end{array}$ & $62.86 \mathrm{k}$ & $55.79^{\mathrm{h}}$ & $36.30^{\mathrm{a}}$ & $53.74^{\mathrm{g}}$ & $47.79^{d}$ & $43.20^{c}$ & $47.45^{\mathrm{d}}$ & $47.94^{\mathrm{d}}$ & $39.63^{b}$ & $44.57^{\mathrm{c}}$ & $49.80^{\mathrm{e}}$ & $52.14^{\mathrm{f}}$ & $52.87^{\mathrm{fg}}$ & $50.73^{\mathrm{e}}$ & $53.64^{\mathrm{g}}$ & $49.19^{\mathrm{e}}$ & $54.70^{g h}$ & $55.38^{\mathrm{h}}$ & $46.64^{\mathrm{d}}$ & $56.74^{\mathrm{hi}}$ & $57.78^{\mathrm{i}}$ & $59.14^{\mathrm{j}}$ \\
\hline 2 & Myristic acid (C14:0) & $0.03^{\mathrm{ab}}$ & $0.03^{\mathrm{ab}}$ & $<0.01$ & $0.05^{\mathrm{ab}}$ & $<0.01$ & $0.02^{\mathrm{a}}$ & $0.22^{\mathrm{d}}$ & $0.02^{\mathrm{a}}$ & $0.02^{\mathrm{a}}$ & $0.05^{\mathrm{ab}}$ & $0.03^{\mathrm{a}}$ & $0.05^{\mathrm{b}}$ & $0.10^{\mathrm{c}}$ & $0.07^{\mathrm{b}}$ & $<0.01$ & $<0.01$ & $0.03^{\mathrm{a}}$ & $0.02^{\mathrm{a}}$ & $<0.01$ & $0.03^{\mathrm{a}}$ & $0.03^{\mathrm{ab}}$ & $0.02^{\mathrm{a}}$ & $0.03^{\mathrm{ab}}$ \\
\hline 3 & $\begin{array}{l}\text { Pentadecanoic acid } \\
\text { (C15:0) }\end{array}$ & $<0.01$ & $0.01^{\mathrm{a}}$ & $<0.01$ & $0.01^{\mathrm{a}}$ & $<0.01$ & $<0.01$ & $<0.01$ & $0.03^{\mathrm{a}}$ & $0.02^{\mathrm{a}}$ & $<0.01$ & $<0.01$ & $0.02^{\mathrm{a}}$ & $<0.01$ & $0.06^{\mathrm{b}}$ & $<0.01$ & $<0.01$ & $0.02^{\mathrm{a}}$ & $0.02^{\mathrm{a}}$ & $0.02^{\mathrm{a}}$ & $<0.01$ & $0.01^{\mathrm{a}}$ & $0.01^{\mathrm{a}}$ & $<0.01$ \\
\hline 4 & Palmitic acid (C16:0) & $5.84^{\mathrm{f}}$ & $5.53^{\mathrm{i}}$ & $5.81^{\mathrm{gh}}$ & $5.31^{\mathrm{a}}$ & $5.21^{\mathrm{de}}$ & $5.14^{\mathrm{c}}$ & $6.48^{\mathrm{de}}$ & $5.45^{\mathrm{cd}}$ & $5.63^{\mathrm{d}}$ & $4.91^{\mathrm{a}}$ & $5.41^{\mathrm{c}}$ & $6.37^{\mathrm{g}}$ & $4.98^{\mathrm{cd}}$ & $5.16^{\mathrm{d}}$ & $4.93^{\mathrm{c}}$ & $5.37^{\mathrm{e}}$ & $5.63^{\mathrm{d}}$ & $4.68^{\mathrm{cd}}$ & $5.22^{\mathrm{e}}$ & $5.09^{\mathrm{b}}$ & $6.43^{\mathrm{j}}$ & $5.74^{\mathrm{h}}$ & $5.77^{\text {hi }}$ \\
\hline 5 & Palmitoleic acid (C16:1) & $0.36^{\mathrm{cd}}$ & $0.29^{c}$ & $0.32^{\mathrm{c}}$ & $0.27^{\mathrm{a}}$ & $0.31^{\mathrm{bc}}$ & $0.37^{c}$ & $0.37^{\mathrm{bc}}$ & $0.24^{\mathrm{a}}$ & $0.27^{\mathrm{ab}}$ & $0.28^{\mathrm{a}}$ & $0.34^{\mathrm{b}}$ & $0.35^{\mathrm{c}}$ & $0.30^{\mathrm{bc}}$ & $0.42^{\mathrm{de}}$ & $0.34^{c}$ & $0.26^{\mathrm{b}}$ & $0.41^{\mathrm{d}}$ & $0.38^{\mathrm{d}}$ & $0.30^{c}$ & $0.30^{\mathrm{b}}$ & $0.56^{\mathrm{f}}$ & $0.38^{\mathrm{de}}$ & $0.38^{\mathrm{de}}$ \\
\hline 6 & $\begin{array}{l}\text { Heptadecanoic acid } \\
\text { (C17:0) }\end{array}$ & $0.06^{\mathrm{a}}$ & $0.07^{\mathrm{b}}$ & $0.10^{\mathrm{b}}$ & $0.06^{\mathrm{a}}$ & $0.11^{\mathrm{b}}$ & $0.06^{\mathrm{a}}$ & $0.07^{\mathrm{a}}$ & $0.07^{\mathrm{a}}$ & $0.06^{\mathrm{a}}$ & $0.06^{\mathrm{a}}$ & $0.06^{\mathrm{a}}$ & $0.06^{\mathrm{a}}$ & $0.10^{\mathrm{b}}$ & $0.07^{\mathrm{ab}}$ & $0.09^{\mathrm{ab}}$ & $0.07^{\mathrm{ab}}$ & $0.06^{\mathrm{a}}$ & $0.07^{\mathrm{ab}}$ & $0.06^{\mathrm{ab}}$ & $0.06^{\mathrm{a}}$ & $0.06^{\mathrm{a}}$ & $0.08^{\mathrm{ab}}$ & $0.06^{\mathrm{ab}}$ \\
\hline 7 & $\begin{array}{l}\text { cis-10 Heptadecenoic } \\
\text { acid (C17:1) }\end{array}$ & $0.10^{\mathrm{b}}$ & $0.09^{\mathrm{b}}$ & $0.11^{\mathrm{bc}}$ & $0.11^{\mathrm{b}}$ & $0.09^{\mathrm{b}}$ & $0.15^{\mathrm{c}}$ & $0.11^{\mathrm{b}}$ & $0.08^{\mathrm{b}}$ & $0.11^{\mathrm{b}}$ & $0.11^{\mathrm{b}}$ & $0.12^{\mathrm{b}}$ & $0.10^{\mathrm{b}}$ & $0.17^{\mathrm{d}}$ & $0.12^{c}$ & $0.11^{\mathrm{bc}}$ & $0.03^{\mathrm{a}}$ & $0.11^{\mathrm{b}}$ & $0.11^{\mathrm{bc}}$ & $0.09^{\mathrm{b}}$ & $0.11^{\mathrm{b}}$ & $0.10^{\mathrm{bc}}$ & $0.07^{\mathrm{b}}$ & $0.10^{\mathrm{bc}}$ \\
\hline 8 & Stearic acid (C18:0) & $1.73^{\mathrm{c}}$ & $2.37^{\mathrm{f}}$ & $2.11^{\mathrm{d}}$ & $1.99^{\mathrm{b}}$ & $1.88^{\mathrm{cd}}$ & $1.51^{\mathrm{b}}$ & $2.18^{\mathrm{c}}$ & $1.97^{\mathrm{c}}$ & $1.52^{\mathrm{b}}$ & $1.45^{\mathrm{a}}$ & $1.94^{\mathrm{bc}}$ & $1.75^{\mathrm{bc}}$ & $2.17^{\mathrm{d}}$ & $1.57^{\mathrm{bc}}$ & $1.96^{\mathrm{cd}}$ & $2.24^{\mathrm{e}}$ & $1.72^{\mathrm{bc}}$ & $1.47^{\mathrm{bc}}$ & $2.23^{\mathrm{e}}$ & $1.67^{\mathrm{b}}$ & $1.58^{\mathrm{c}}$ & $2.56^{\mathrm{g}}$ & $2.17^{\mathrm{e}}$ \\
\hline 9 & Oleic acid (C18:1 n9c) & $66.12^{\mathrm{d}}$ & $66.48^{\mathrm{ef}}$ & $68.07^{\mathrm{e}}$ & $67.89^{\mathrm{a}}$ & $70.94^{\mathrm{e}}$ & $64.69^{\mathrm{bc}}$ & $65.56^{\mathrm{b}}$ & $63.14^{\mathrm{b}}$ & $65.95^{\mathrm{c}}$ & $77.37^{\mathrm{bc}}$ & $70.07^{\mathrm{c}}$ & $65.08^{\mathrm{c}}$ & $72.93^{e}$ & $75.38^{\mathrm{e}}$ & $72.52^{\mathrm{de}}$ & $68.72^{\mathrm{de}}$ & $71.04^{\mathrm{d}}$ & $74.61^{\mathrm{ef}}$ & $75.76^{\mathrm{f}}$ & $71.10^{\mathrm{d}}$ & $70.62^{\mathrm{ef}}$ & $68.22^{\mathrm{e}}$ & $74.59^{\mathrm{g}}$ \\
\hline 10 & $\begin{array}{l}\text { Linoleic acid } \\
\text { (C18:2n6c) }\end{array}$ & $25.48^{\text {de }}$ & $24.80^{\mathrm{f}}$ & $22.32^{\mathrm{d}}$ & $24.08^{\mathrm{b}}$ & $21.22^{\mathrm{cd}}$ & $27.72^{\mathrm{d}}$ & $24.66^{c}$ & $28.69^{d}$ & $26.17^{\mathrm{d}}$ & $15.57^{\mathrm{a}}$ & $21.75^{\mathrm{b}}$ & $26.04^{\mathrm{d}}$ & $18.83^{\mathrm{b}}$ & $16.80^{\mathrm{b}}$ & $19.63^{\mathrm{b}}$ & $23.01^{\mathrm{d}}$ & $19.99^{\mathrm{bc}}$ & $18.31^{\mathrm{c}}$ & $16.05^{\mathrm{b}}$ & $21.34^{\mathrm{bc}}$ & $20.32^{\mathrm{cd}}$ & $22.63^{\mathrm{de}}$ & $16.60^{b c}$ \\
\hline 11 & Arachidic acid (C20:0) & $0.10^{\mathrm{ab}}$ & $0.12^{\mathrm{c}}$ & $0.12^{\mathrm{bc}}$ & $0.10^{\mathrm{a}}$ & $0.10^{\mathrm{ab}}$ & $0.09^{\mathrm{a}}$ & $0.11^{\mathrm{ab}}$ & $0.11^{\mathrm{ab}}$ & $0.09^{\mathrm{a}}$ & $0.08^{\mathrm{a}}$ & $0.09^{\mathrm{a}}$ & $0.08^{\mathrm{a}}$ & $0.14^{\mathrm{c}}$ & $0.10^{\mathrm{ab}}$ & $0.13^{\mathrm{bc}}$ & $0.11^{\mathrm{b}}$ & $0.07^{\mathrm{a}}$ & $0.09^{\mathrm{ab}}$ & $0.10^{\mathrm{ab}}$ & $0.09^{\mathrm{a}}$ & $0.06^{\mathrm{a}}$ & $0.09^{\mathrm{ab}}$ & $0.09^{\mathrm{ab}}$ \\
\hline 12 & $\begin{array}{l}\text { cis-11-Eicosenoic acid } \\
(\mathrm{C} 20: 1)\end{array}$ & $0.08^{\mathrm{a}}$ & $0.10^{\mathrm{ab}}$ & $0.12^{\mathrm{bc}}$ & $0.11^{\mathrm{a}}$ & $0.06^{\mathrm{a}}$ & $0.10^{\mathrm{ab}}$ & $0.09^{\mathrm{a}}$ & $0.10^{\mathrm{ab}}$ & $0.10^{\mathrm{ab}}$ & $0.11^{\mathrm{a}}$ & $0.12^{\mathrm{ab}}$ & $0.08^{\mathrm{a}}$ & $0.16^{\mathrm{c}}$ & $0.12^{\mathrm{bc}}$ & $0.13^{\mathrm{bc}}$ & $0.09^{\mathrm{ab}}$ & $0.09^{\mathrm{ab}}$ & $0.14^{c}$ & $0.09^{\mathrm{ab}}$ & $0.11^{\mathrm{ab}}$ & $0.07^{\mathrm{a}}$ & $0.09^{\mathrm{ab}}$ & $0.09^{\mathrm{ab}}$ \\
\hline 13 & $\begin{array}{l}\alpha \text {-Linolenic acid (C18:3 } \\
\text { n3) }\end{array}$ & $0.04^{\mathrm{a}}$ & $0.04^{\mathrm{ab}}$ & $0.72^{\mathrm{b}}$ & $0.03^{\mathrm{a}}$ & $0.04^{\mathrm{a}}$ & $0.09^{\mathrm{a}}$ & $0.04^{\mathrm{a}}$ & $0.05^{\mathrm{a}}$ & $0.03^{\mathrm{a}}$ & $<0.01$ & $0.04^{\mathrm{a}}$ & $0.04^{\mathrm{a}}$ & $0.06^{\mathrm{ab}}$ & $0.05^{\mathrm{ab}}$ & $0.03^{\mathrm{a}}$ & $0.03^{\mathrm{a}}$ & $0.80^{\mathrm{b}}$ & $0.03^{\mathrm{a}}$ & $0.03^{\mathrm{a}}$ & $0.04^{\mathrm{a}}$ & $0.03^{\mathrm{a}}$ & $0.02^{\mathrm{a}}$ & $0.03^{\mathrm{a}}$ \\
\hline 14 & Behenic acid (C22:0) & $0.02^{\mathrm{a}}$ & $0.03^{\mathrm{ab}}$ & $0.10^{c}$ & $<0.01$ & $<0.01$ & $<0.01$ & $0.03^{\mathrm{a}}$ & $0.03^{\mathrm{a}}$ & $0.02^{\mathrm{a}}$ & $0.02^{\mathrm{a}}$ & $0.03^{\mathrm{a}}$ & $0.02^{\mathrm{a}}$ & $<0.01$ & $<0.01$ & $<0.01$ & $0.04^{\mathrm{ab}}$ & $0.02^{\mathrm{a}}$ & $0.06^{\mathrm{b}}$ & $0.02^{\mathrm{a}}$ & $0.01^{\mathrm{a}}$ & $0.02^{\mathrm{a}}$ & $0.02^{\mathrm{a}}$ & $0.02^{\mathrm{a}}$ \\
\hline 15 & $\begin{array}{l}\text { Docosadienoic acid } \\
\text { (C22:2 cis } 13,16)\end{array}$ & $<0.01$ & $0.01^{\mathrm{a}}$ & $<0.01$ & $<0.01$ & $<0.01$ & $<0.01$ & $<0.01$ & $<0.01$ & $<0.01$ & $<0.01$ & $<0.01$ & $<0.01$ & $<0.01$ & $<0.01$ & $<0.01$ & $<0.01$ & $<0.01$ & $<0.01$ & $<0.01$ & $<0.01$ & $<0.01$ & $<0.01$ & $<0.01$ \\
\hline 16 & $\begin{array}{l}\text { Tricosanoic acid } \\
(\mathrm{C} 23: 0)\end{array}$ & $0.04^{\mathrm{a}}$ & $<0.01$ & $0.10^{\mathrm{d}}$ & $<0.01$ & $0.05^{\mathrm{a}}$ & $0.06^{\mathrm{ab}}$ & $0.09^{\mathrm{bc}}$ & $0.03^{\mathrm{a}}$ & $0.01^{\mathrm{a}}$ & $<0.01$ & $0.02^{\mathrm{a}}$ & $0.03^{\mathrm{a}}$ & $0.07^{\mathrm{bc}}$ & $0.10^{\text {cd }}$ & $0.13^{\mathrm{d}}$ & $0.03^{\mathrm{a}}$ & $0.01^{\mathrm{a}}$ & $0.03^{\mathrm{a}}$ & $0.03^{\mathrm{a}}$ & $0.06^{\mathrm{ab}}$ & $0.11^{\mathrm{d}}$ & $0.06^{\mathrm{ab}}$ & $0.09^{\text {cd }}$ \\
\hline 17 & Lignoceric acid (C24:0) & $<0.01$ & 0.03 & $<0.01$ & $<0.01$ & $<0.01$ & $<0.01$ & $<0.01$ & $<0.01$ & $<0.01$ & $<0.01$ & $<0.01$ & $<0.01$ & $<0.01$ & $<0.01$ & $<0.01$ & $<0.01$ & $<0.01$ & $<0.01$ & $<0.01$ & $<0.01$ & $<0.01$ & $<0.01$ & $<0.01$ \\
\hline & Oleic/Linoleic ratio & $2.59^{\mathrm{b}}$ & $2.68^{\mathrm{b}}$ & $3.05^{\mathrm{d}}$ & $2.82^{\mathrm{c}}$ & $3.34^{\mathrm{ef}}$ & $2.33^{\mathrm{a}}$ & $2.66^{\mathrm{b}}$ & $2.20^{\mathrm{a}}$ & $2.52^{\mathrm{b}}$ & $4.97^{\mathrm{j}}$ & $3.22^{\mathrm{e}}$ & $2.50^{\mathrm{b}}$ & $3.87^{g}$ & $4.49^{\mathrm{h}}$ & $3.69^{\mathrm{fg}}$ & $2.99^{\mathrm{d}}$ & $3.55^{\mathrm{f}}$ & $4.07^{\mathrm{g}}$ & $4.72^{\mathrm{i}}$ & $3.33^{\mathrm{ef}}$ & $3.47^{\mathrm{f}}$ & $3.01^{\mathrm{d}}$ & $4.49^{\mathrm{h}}$ \\
\hline
\end{tabular}

" Different letters in the same row denote a significant difference according to Tukey's test, $\mathrm{p}<0.05$. 
Table 3

Radical scavenging activity (RSA), total phenolic content (TPC), and content of phenolic compounds in almond samples. (ND = not detected compound).

\begin{tabular}{|c|c|c|c|c|c|c|c|c|c|c|c|c|c|c|c|c|c|c|c|c|c|c|c|c|}
\hline $\mathrm{N}^{\mathrm{o}^{*}}$ & & $1 / 03$ & 3/03 & 4/03 & $10 / 03$ & $11 / 03$ & $12 / 03$ & $13 / 03$ & $14 / 03$ & $15 / 03$ & $16 / 03$ & $18 / 03$ & $19 / 03$ & $23 / 03$ & $24 / 03$ & $25 / 03$ & $27 / 03$ & $28 / 03$ & $1 / 05$ & ZD 1 & ZD 2 & Marcona & Troito & Texas \\
\hline 18 & RSA (mmol TE/kg FW) & $9^{\mathrm{cd}^{* *}}$ & $10^{\text {cd }}$ & $18^{\text {ef }}$ & $7^{\mathrm{c}}$ & $2^{a}$ & $10^{\text {cd }}$ & $12^{\mathrm{d}}$ & $2^{\mathrm{a}}$ & $19^{\mathrm{ef}}$ & $1^{\mathrm{a}}$ & $24^{\mathrm{g}}$ & $2 \mathrm{a}$ & $11^{\mathrm{d}}$ & $4^{\mathrm{b}}$ & $18^{\mathrm{e}}$ & $3^{\mathrm{ab}}$ & $16^{\mathrm{e}}$ & $2^{\mathrm{a}}$ & $10^{\text {cd }}$ & $3^{\mathrm{ab}}$ & $1^{\mathrm{a}}$ & $1^{\mathrm{a}}$ & $20^{\mathrm{f}}$ \\
\hline 19 & $\mathrm{TPC}(\mathrm{mg} \mathrm{GAE} / \mathrm{kg} \mathrm{FW})$ & $593^{\mathrm{e}}$ & $757^{\mathrm{g}}$ & $1145^{\mathrm{ij}}$ & $788^{\mathrm{g}}$ & $473^{\mathrm{d}}$ & $390^{\mathrm{c}}$ & $879^{\mathrm{h}}$ & $464^{\mathrm{d}}$ & $1319^{k}$ & $382^{\mathrm{c}}$ & $1392^{\mathrm{k}}$ & $457 d$ & $902^{\mathrm{h}}$ & $683^{f}$ & $1106^{\mathrm{i}}$ & $461^{\mathrm{d}}$ & $819^{\mathrm{g}}$ & $448^{\mathrm{d}}$ & $890^{\mathrm{h}}$ & $621^{\mathrm{e}}$ & $204^{\mathrm{a}}$ & $271^{\mathrm{b}}$ & $1195^{\mathrm{j}}$ \\
\hline \multicolumn{25}{|c|}{ Hydroxybenzoic acid derivatives (mg/kg) } \\
\hline 20 & Protocatechuic acid & $0.75^{\mathrm{ef}}$ & ND & $0.32^{\mathrm{a}}$ & ND & $0.60^{\text {cd }}$ & $0.74^{\mathrm{ef}}$ & $0.67^{\mathrm{de}}$ & $0.85^{\mathrm{g}}$ & $1.07^{\mathrm{h}}$ & $0.56^{\mathrm{c}}$ & $1.20^{\mathrm{i}}$ & $0.58 \mathrm{c}$ & ND & $0.61^{\mathrm{cd}}$ & $0.43^{\mathrm{b}}$ & $0.54^{\mathrm{c}}$ & $0.64^{\text {cd }}$ & ND & $0.70^{\text {ef }}$ & ND & $0.56^{\mathrm{c}}$ & $0.59^{\text {cd }}$ & $0.77^{\mathrm{f}}$ \\
\hline 21 & $p$-Hydroxybenzoic acid & $0.37^{\mathrm{b}}$ & $0.32^{\mathrm{ab}}$ & $0.19^{\mathrm{a}}$ & $0.45^{\mathrm{d}}$ & $0.40^{\text {cd }}$ & $0.36^{\mathrm{b}}$ & $0.44^{\mathrm{d}}$ & $0.55^{\mathrm{e}}$ & $0.58^{\mathrm{e}}$ & $0.37^{\mathrm{b}}$ & $0.56^{\mathrm{e}}$ & $0.40^{\text {cd }}$ & $0.42^{\mathrm{cd}}$ & $0.35^{\mathrm{b}}$ & $0.24^{\mathrm{a}}$ & $0.55^{\mathrm{e}}$ & $0.30^{\mathrm{ab}}$ & $0.32^{\mathrm{ab}}$ & $0.28^{\mathrm{ab}}$ & $0.26^{\mathrm{ab}}$ & $0.37^{\mathrm{b}}$ & $0.69^{f}$ & $0.39^{\text {cd }}$ \\
\hline 22 & Ellagic acid & $0.12^{\mathrm{b}}$ & ND & $0.09^{\mathrm{b}}$ & ND & $0.08^{\mathrm{b}}$ & $0.06^{\mathrm{ab}}$ & ND & $1.35^{\mathrm{e}}$ & $0.06^{\mathrm{ab}}$ & ND & $0.03^{\mathrm{a}}$ & ND & $0.04^{\mathrm{a}}$ & ND & ND & $0.02^{\mathrm{a}}$ & $\mathrm{ND}$ & $0.11^{\mathrm{b}}$ & ND & ND & $0.13^{\mathrm{b}}$ & $0.35^{\mathrm{d}}$ & $0.21^{\mathrm{c}}$ \\
\hline 23 & Vanillic acid & $1.55^{\mathrm{g}}$ & $2.78^{\mathrm{n}}$ & $0.79^{c}$ & $1.44^{\mathrm{f}}$ & $0.92^{\mathrm{d}}$ & $1.65^{\mathrm{h}}$ & $1.62^{\mathrm{h}}$ & $2.30^{\mathrm{k}}$ & $2.61^{\mathrm{m}}$ & $0.38^{\mathrm{a}}$ & $0.89^{d}$ & $0.98^{\mathrm{d}}$ & $2.84^{\mathrm{n}}$ & $2.44^{1}$ & $1.60^{\mathrm{h}}$ & $0.48^{\mathrm{b}}$ & $1.69^{\mathrm{h}}$ & $1.12^{\mathrm{e}}$ & $1.82^{\mathrm{i}}$ & $1.95^{\mathrm{j}}$ & $0.92^{\mathrm{d}}$ & $0.92^{\mathrm{d}}$ & $2.28^{\mathrm{k}}$ \\
\hline \multicolumn{25}{|c|}{ Hydroxycinnamic acid derivatives $(\mathrm{mg} / \mathrm{kg}$ ) } \\
\hline 24 & Aesculin & $0.37^{\mathrm{d}}$ & $0.21^{\mathrm{a}}$ & $0.23^{\mathrm{ab}}$ & ND & $0.23^{\mathrm{ab}}$ & $0.21^{\mathrm{a}}$ & $0.28^{\mathrm{c}}$ & $0.25^{\mathrm{b}}$ & $0.31^{\mathrm{c}}$ & $0.24^{\mathrm{b}}$ & $0.28^{\mathrm{c}}$ & $0.21^{\mathrm{a}}$ & $0.19^{\mathrm{a}}$ & $0.20^{\mathrm{a}}$ & $0.21^{\mathrm{a}}$ & $0.26^{\mathrm{b}}$ & $0.21^{\mathrm{a}}$ & $0.19^{\mathrm{a}}$ & $0.20^{\mathrm{a}}$ & $0.22^{\mathrm{a}}$ & $0.22^{\mathrm{a}}$ & $0.20^{\mathrm{a}}$ & $0.22^{\mathrm{a}}$ \\
\hline 25 & Chlorogenic acid & $2.11^{\mathrm{e}}$ & $4.89^{\mathrm{i}}$ & $21.03^{\mathrm{m}}$ & $1.05^{\mathrm{a}}$ & $5.47^{\mathrm{i}}$ & $4.38^{\mathrm{h}}$ & $1.08^{\mathrm{a}}$ & $1.32^{\mathrm{b}}$ & $7.99^{\mathrm{k}}$ & $0.98^{\mathrm{a}}$ & $13.62^{1}$ & $1.87^{\mathrm{d}}$ & $3.83^{\mathrm{g}}$ & $1.33^{\mathrm{b}}$ & $3.05^{\mathrm{f}}$ & $1.23^{\mathrm{b}}$ & $1.59^{\mathrm{c}}$ & $1.20^{\mathrm{b}}$ & $5.34^{\mathrm{i}}$ & $2.14^{\mathrm{e}}$ & $1.35^{\mathrm{b}}$ & $0.99^{\mathrm{a}}$ & $6.93^{\mathrm{j}}$ \\
\hline 26 & Aesculetin & $0.27^{\mathrm{e}}$ & $0.57^{\mathrm{i}}$ & $0.79^{\mathrm{k}}$ & $0.55^{\mathrm{hi}}$ & $0.23^{\mathrm{d}}$ & $0.08^{\mathrm{a}}$ & $0.31^{\mathrm{f}}$ & $0.19^{c}$ & $0.26^{\mathrm{e}}$ & $0.08^{\mathrm{a}}$ & $0.23^{\mathrm{d}}$ & $0.13^{\mathrm{b}}$ & $0.52^{\mathrm{g}}$ & $0.26^{\mathrm{e}}$ & $0.81^{\mathrm{k}}$ & $0.28^{\mathrm{ef}}$ & $0.30^{\mathrm{f}}$ & $0.23^{\mathrm{d}}$ & $0.27^{\mathrm{e}}$ & $0.68^{\mathrm{j}}$ & $0.11^{\mathrm{b}}$ & $0.17^{\mathrm{c}}$ & $0.19^{c}$ \\
\hline 27 & Caffeic acid & $0.82^{\mathrm{c}}$ & $0.83^{\mathrm{c}}$ & $0.77^{\mathrm{ab}}$ & $0.79^{\mathrm{b}}$ & $0.76^{\mathrm{ab}}$ & $0.75^{\mathrm{a}}$ & $0.80^{\mathrm{b}}$ & $0.79^{\mathrm{b}}$ & $1.48^{\mathrm{f}}$ & $0.73^{\mathrm{a}}$ & $0.86^{\mathrm{d}}$ & $0.75^{\mathrm{a}}$ & $0.90^{\mathrm{e}}$ & $0.77^{\mathrm{ab}}$ & ND & $0.75^{\mathrm{a}}$ & ND & $0.75^{\mathrm{a}}$ & $0.73^{\mathrm{a}}$ & $0.76^{\mathrm{ab}}$ & $0.78^{\mathrm{b}}$ & ND & $0.74^{\mathrm{a}}$ \\
\hline 28 & $p$-Coumaric acid & $0.72^{\mathrm{h}}$ & $0.21^{\mathrm{bc}}$ & $0.17^{\mathrm{b}}$ & $0.25^{\mathrm{d}}$ & $0.31^{\mathrm{e}}$ & $0.27^{\mathrm{d}}$ & $0.39^{\mathrm{f}}$ & $0.31^{\mathrm{e}}$ & $0.31^{\mathrm{e}}$ & $0.18^{\mathrm{b}}$ & $0.37^{\mathrm{f}}$ & $0.27^{\mathrm{d}}$ & $0.28^{\mathrm{d}}$ & $0.26^{\mathrm{d}}$ & $0.20^{\mathrm{bc}}$ & $0.52^{\mathrm{g}}$ & $0.22^{\mathrm{c}}$ & $0.20^{\mathrm{bc}}$ & $0.22^{\mathrm{c}}$ & $0.26^{\mathrm{d}}$ & $0.14^{\mathrm{a}}$ & $0.19^{\mathrm{b}}$ & $0.18^{\mathrm{b}}$ \\
\hline 29 & Ferulic acid & $0.70^{\mathrm{d}}$ & $1.71^{1}$ & $1.34^{\mathrm{j}}$ & $1.10^{\mathrm{h}}$ & $0.83^{\mathrm{e}}$ & $0.74^{\mathrm{d}}$ & $1.33^{\mathrm{j}}$ & $1.72^{1}$ & $1.36^{\mathrm{j}}$ & $0.58^{\mathrm{c}}$ & $1.64^{\mathrm{k}}$ & $1.16^{\mathrm{i}}$ & $2.81^{\mathrm{m}}$ & $0.84^{\mathrm{e}}$ & $0.70^{\mathrm{d}}$ & $0.71^{\mathrm{d}}$ & $0.41^{\mathrm{b}}$ & $0.99^{\mathrm{g}}$ & $0.81^{\mathrm{e}}$ & $0.89^{\mathrm{f}}$ & $0.73^{\mathrm{d}}$ & $0.25^{\mathrm{a}}$ & $0.59^{c}$ \\
\hline 30 & Sinapic acid & $1.00^{\mathrm{f}}$ & $3.50^{\mathrm{k}}$ & $0.93^{e}$ & $0.74^{\mathrm{c}}$ & $0.56^{\mathrm{a}}$ & $1.15^{\mathrm{h}}$ & $0.77^{\mathrm{c}}$ & $0.57^{\mathrm{a}}$ & $1.08^{\mathrm{g}}$ & ND & $1.03^{\mathrm{f}}$ & $0.65^{\mathrm{b}}$ & $1.65^{\mathrm{i}}$ & $1.16^{\mathrm{h}}$ & $1.96^{\mathrm{j}}$ & ND & $1.08^{\mathrm{g}}$ & $0.69^{\mathrm{b}}$ & $1.03^{\mathrm{f}}$ & $1.68^{\mathrm{i}}$ & ND & ND & $0.82^{\mathrm{d}}$ \\
\hline 31 & Coniferyl aldehyde & $0.20^{c}$ & $0.61^{\mathrm{j}}$ & $0.83^{1}$ & $0.54^{\mathrm{h}}$ & $0.24^{\mathrm{d}}$ & $0.08^{\mathrm{a}}$ & $0.36^{\mathrm{g}}$ & $0.21^{\mathrm{c}}$ & $0.28^{\mathrm{e}}$ & $0.10^{\mathrm{a}}$ & $0.27^{\mathrm{e}}$ & $0.15^{\mathrm{b}}$ & $0.58^{\mathrm{i}}$ & $0.29^{\mathrm{e}}$ & $0.83^{1}$ & $0.21^{\mathrm{c}}$ & $0.33^{\mathrm{f}}$ & $0.22^{\mathrm{c}}$ & $0.30^{\text {ef }}$ & $0.72^{\mathrm{k}}$ & $0.12^{\mathrm{ab}}$ & $0.19^{c}$ & $0.21^{\mathrm{c}}$ \\
\hline \multicolumn{25}{|c|}{ Dihydrochalcones $(\mathrm{mg} / \mathrm{kg})$} \\
\hline 32 & Phlorizin & $0.92^{\mathrm{g}}$ & $1.04^{\mathrm{i}}$ & $2.09^{\mathrm{n}}$ & $0.85^{\mathrm{f}}$ & $1.04^{\mathrm{i}}$ & $0.64^{\mathrm{c}}$ & $1.71^{\mathrm{k}}$ & $0.95^{\mathrm{g}}$ & $1.82^{1}$ & $0.82^{\mathrm{e}}$ & $2.00^{\mathrm{m}}$ & $0.74^{\mathrm{e}}$ & $2.10^{\mathrm{n}}$ & $0.75^{\mathrm{e}}$ & $1.06^{\mathrm{i}}$ & $2.19^{\circ}$ & $1.15^{\mathrm{j}}$ & $0.97^{\mathrm{h}}$ & $0.91^{\mathrm{g}}$ & $0.69^{\mathrm{d}}$ & $0.41^{\mathrm{a}}$ & $0.53^{\mathrm{b}}$ & $1.00^{\mathrm{h}}$ \\
\hline 33 & Phloretin & $0.09^{\mathrm{a}}$ & $0.18^{\mathrm{de}}$ & $0.16^{\mathrm{cd}}$ & $0.13^{\mathrm{b}}$ & $0.14^{\mathrm{bc}}$ & $0.09^{\mathrm{a}}$ & $0.13^{\mathrm{b}}$ & $0.12^{\mathrm{b}}$ & $0.15^{\mathrm{bc}}$ & $0.09^{\mathrm{a}}$ & $0.24^{\mathrm{g}}$ & $0.09^{\mathrm{a}}$ & $0.22^{\mathrm{f}}$ & $0.12^{\mathrm{b}}$ & $0.20^{\mathrm{e}}$ & $0.12^{\mathrm{b}}$ & $0.12^{\mathrm{b}}$ & $0.12^{\mathrm{b}}$ & $0.14^{\mathrm{bc}}$ & $0.16^{\text {cd }}$ & $0.08^{\mathrm{a}}$ & $0.09^{\mathrm{a}}$ & $0.13^{\mathrm{b}}$ \\
\hline \multicolumn{25}{|c|}{ Stilbenoids ( $\mathrm{mg} / \mathrm{kg}$ ) } \\
\hline 34 & Resveratrol & $0.07^{\mathrm{ab}}$ & $0.12^{\mathrm{d}}$ & $0.08^{\mathrm{b}}$ & $0.09^{\mathrm{bc}}$ & $0.06^{\mathrm{a}}$ & $0.10^{c}$ & $0.10^{\mathrm{c}}$ & $0.07^{\mathrm{ab}}$ & $0.11^{\mathrm{cd}}$ & ND & $0.06^{\mathrm{a}}$ & ND & $0.07^{\mathrm{ab}}$ & $0.06^{\mathrm{a}}$ & $0.10^{\mathrm{c}}$ & $0.07^{\mathrm{ab}}$ & $0.16^{\mathrm{e}}$ & $0.07^{\mathrm{ab}}$ & $0.10^{c}$ & $0.10^{c}$ & ND & $0.08^{\mathrm{b}}$ & $0.11^{\mathrm{cd}}$ \\
\hline \multicolumn{25}{|c|}{ Flavonoids and derivatives $(\mathrm{mg} / \mathrm{kg})$} \\
\hline 35 & Catechin & $26.04^{\mathrm{j}}$ & $32.91^{1}$ & $49.93^{\mathrm{p}}$ & $26.25^{\mathrm{j}}$ & $10.85^{\mathrm{d}}$ & $21.95^{\mathrm{h}}$ & $25.18^{\mathrm{ij}}$ & $17.78^{\mathrm{f}}$ & $31.00^{1}$ & $4.76^{\mathrm{b}}$ & $30.04^{\mathrm{kl}}$ & $10.78^{\mathrm{d}}$ & $32.15^{1}$ & $19.38^{g}$ & $80.75^{\mathrm{q}}$ & $17.06^{\mathrm{f}}$ & $29.41^{\mathrm{k}}$ & $12.84^{\mathrm{e}}$ & $47.99^{\circ}$ & $35.41^{\mathrm{m}}$ & $2.67^{\mathrm{a}}$ & $6.85^{\mathrm{c}}$ & $41.44^{\mathrm{n}}$ \\
\hline 36 & Rutin & $0.72^{\mathrm{a}}$ & $11.33^{\mathrm{k}}$ & $0.61^{\mathrm{a}}$ & $3.45^{\mathrm{i}}$ & $1.49^{\mathrm{b}}$ & $4.10^{\mathrm{j}}$ & $1.57^{\mathrm{bc}}$ & $0.74^{\mathrm{a}}$ & $1.76^{\mathrm{d}}$ & $1.62^{\mathrm{c}}$ & $2.76^{\mathrm{h}}$ & $2.19^{f}$ & ND & $0.61^{\mathrm{a}}$ & $2.31^{\mathrm{g}}$ & $2.89^{\mathrm{h}}$ & $3.01^{\mathrm{h}}$ & $1.90^{\mathrm{e}}$ & $1.75^{\mathrm{d}}$ & $2.13^{\mathrm{f}}$ & $0.70^{\mathrm{a}}$ & ND & $1.87^{\text {de }}$ \\
\hline 37 & Hyperoside & $0.50^{\mathrm{b}}$ & $5.84^{\mathrm{m}}$ & $0.66^{\mathrm{d}}$ & $1.28^{\mathrm{j}}$ & $0.49^{\mathrm{b}}$ & $0.60^{c}$ & $1.00^{\mathrm{i}}$ & $0.51^{\mathrm{b}}$ & $0.73^{\mathrm{e}}$ & $0.33^{\mathrm{a}}$ & $0.90^{\mathrm{h}}$ & $1.58^{1}$ & $0.93^{\mathrm{h}}$ & $0.50^{\mathrm{b}}$ & $1.41^{\mathrm{k}}$ & $1.01^{\mathrm{i}}$ & $0.69^{d}$ & $0.93^{\mathrm{h}}$ & $0.79^{\mathrm{f}}$ & $0.88^{\text {gh }}$ & $0.30^{\mathrm{a}}$ & $0.80^{\mathrm{f}}$ & $0.82^{\mathrm{f}}$ \\
\hline 38 & Cynaroside & $4.25^{1}$ & ND & $4.79^{\mathrm{m}}$ & ND & ND & ND & $2.21^{\mathrm{j}}$ & $0.72^{\mathrm{c}}$ & $1.78^{\mathrm{i}}$ & ND & $1.77^{\mathrm{i}}$ & ND & ND & ND & $1.15^{\mathrm{d}}$ & $3.39^{k}$ & ND & ND & ND & $0.52^{\mathrm{b}}$ & $0.21^{\mathrm{a}}$ & ND & ND \\
\hline 39 & Naringin & ND & $0.11^{\mathrm{h}}$ & ND & $0.05^{c}$ & ND & ND & ND & ND & ND & $0.03^{\mathrm{a}}$ & ND & ND & ND & $0.06^{\mathrm{d}}$ & ND & $0.03^{\mathrm{a}}$ & $0.05^{\mathrm{c}}$ & ND & $0.07^{\mathrm{e}}$ & $0.09^{f}$ & $0.04^{\mathrm{b}}$ & ND & $0.06^{\mathrm{d}}$ \\
\hline 40 & Astragalin & ND & $8.66^{\mathrm{j}}$ & ND & $6.19^{\mathrm{h}}$ & $1.18^{\mathrm{b}}$ & ND & $1.44^{\mathrm{b}}$ & ND & $1.24^{\mathrm{b}}$ & $0.95^{\mathrm{a}}$ & $2.60^{\mathrm{d}}$ & 0.00 & $7.77^{\mathrm{i}}$ & ND & $4.68^{\mathrm{g}}$ & $6.11^{\mathrm{h}}$ & $2.82^{\mathrm{e}}$ & $2.58^{\mathrm{d}}$ & $2.67 \mathrm{~d}^{\mathrm{e}}$ & $3.20^{\mathrm{f}}$ & ND & ND & $2.43^{c}$ \\
\hline 41 & Luteolin & $4.27^{\mathrm{m}}$ & $3.24^{\mathrm{k}}$ & $2.81^{\mathrm{k}}$ & $2.31^{\mathrm{j}}$ & $0.48^{\mathrm{b}}$ & $0.76^{\mathrm{e}}$ & $0.82^{\mathrm{f}}$ & $0.74^{\text {de }}$ & $1.31^{\mathrm{h}}$ & $0.59^{c}$ & $6.24^{\mathrm{n}}$ & $1.07^{g}$ & $3.78^{1}$ & $0.74^{\mathrm{de}}$ & $1.07^{\mathrm{g}}$ & $4.23^{\mathrm{m}}$ & $0.45^{\mathrm{b}}$ & $2.21^{\mathrm{j}}$ & $0.69^{\mathrm{d}}$ & $1.71^{\mathrm{i}}$ & $0.34^{\mathrm{a}}$ & $1.09^{\mathrm{g}}$ & $0.45^{\mathrm{b}}$ \\
\hline 42 & Apigenin & $9.94^{\mathrm{s}}$ & $6.55^{\mathrm{p}}$ & $4.96^{\circ}$ & $6.08^{\mathrm{q}}$ & $0.31^{\mathrm{c}}$ & $0.95^{\mathrm{h}}$ & $1.05^{\mathrm{jk}}$ & $0.46^{\mathrm{e}}$ & $1.01^{\mathrm{ij}}$ & $0.53^{\mathrm{f}}$ & $7.70^{\mathrm{r}}$ & $0.57^{\mathrm{f}}$ & $10.47^{t}$ & $0.63^{\mathrm{g}}$ & $1.09^{\mathrm{k}}$ & $4.81^{\mathrm{n}}$ & $0.35^{\mathrm{c}}$ & $4.94^{\circ}$ & $0.40^{\mathrm{d}}$ & $1.86^{1}$ & $0.10^{\mathrm{a}}$ & $2.30^{\mathrm{m}}$ & $0.18^{\mathrm{b}}$ \\
\hline 43 & Naringenin & $14.49^{t}$ & $9.72^{\mathrm{r}}$ & $7.29^{\circ}$ & $9.06^{9}$ & $0.44^{\mathrm{c}}$ & $1.39^{\mathrm{h}}$ & $1.49^{\mathrm{jk}}$ & $0.63 e$ & $1.45^{\mathrm{ij}}$ & $0.76^{\mathrm{f}}$ & $11.43^{\mathrm{s}}$ & $0.77^{\mathrm{f}}$ & $15.74^{\mathrm{u}}$ & $0.88^{\mathrm{g}}$ & $1.52^{\mathrm{k}}$ & $7.12^{\mathrm{n}}$ & $0.48^{\mathrm{c}}$ & $7.37^{\mathrm{p}}$ & $0.54^{\mathrm{d}}$ & $2.68^{1}$ & $0.09^{\mathrm{a}}$ & $3.31^{\mathrm{m}}$ & $0.22^{\mathrm{b}}$ \\
\hline 44 & Kaempferol & $1.10^{\mathrm{h}}$ & $2.63^{\mathrm{i}}$ & $0.82^{\mathrm{e}}$ & $2.22^{\mathrm{k}}$ & $0.60^{\mathrm{a}}$ & $0.76^{\mathrm{d}}$ & $0.65^{\mathrm{ab}}$ & $0.67^{\mathrm{bc}}$ & $0.61^{\mathrm{a}}$ & $0.61^{\mathrm{a}}$ & $2.04^{\mathrm{i}}$ & $0.72^{\text {cd }}$ & $1.58^{\mathrm{i}}$ & $0.61^{\mathrm{a}}$ & $0.82^{\mathrm{e}}$ & $1.11^{\mathrm{h}}$ & $0.67^{\mathrm{b}}$ & $1.04^{\mathrm{g}}$ & $0.64^{\mathrm{ab}}$ & $0.93^{\mathrm{f}}$ & ND & $0.96^{\mathrm{f}}$ & $0.62^{\mathrm{a}}$ \\
\hline 45 & Chrysin & $0.03^{\mathrm{b}}$ & $0.07^{\mathrm{d}}$ & $0.05^{c}$ & $0.04^{\mathrm{bc}}$ & $0.01^{\mathrm{a}}$ & $0.02^{\mathrm{ab}}$ & ND & $0.08^{\mathrm{d}}$ & $0.03^{\mathrm{b}}$ & $0.01^{\mathrm{a}}$ & $0.04^{\mathrm{bc}}$ & ND & $0.05^{c}$ & $0.02^{\mathrm{ab}}$ & ND & $0.02^{\mathrm{ab}}$ & $0.03^{\mathrm{b}}$ & $0.03^{\mathrm{b}}$ & $0.02^{\mathrm{ab}}$ & ND & $0.01^{\mathrm{a}}$ & $0.08^{\mathrm{d}}$ & $0.02^{\mathrm{ab}}$ \\
\hline 46 & Pinocembrin & $0.04^{\mathrm{b}}$ & $0.12^{\mathrm{e}}$ & $0.11^{\mathrm{de}}$ & $0.06^{\mathrm{c}}$ & ND & $0.01^{\mathrm{a}}$ & $0.02^{\mathrm{ab}}$ & $0.03^{\mathrm{b}}$ & $0.02^{\mathrm{ab}}$ & ND & $0.06^{\mathrm{c}}$ & $0.01^{\mathrm{a}}$ & $0.13^{\mathrm{e}}$ & $0.02^{\mathrm{ab}}$ & $0.01^{\mathrm{a}}$ & $0.03^{\mathrm{b}}$ & $0.01^{\mathrm{a}}$ & $0.04^{\mathrm{b}}$ & ND & $0.02^{\mathrm{ab}}$ & ND & $0.10^{\mathrm{d}}$ & ND \\
\hline 47 & Galangin & ND & ND & $0.46^{c}$ & ND & ND & ND & ND & $0.47^{c}$ & ND & $0.36^{\mathrm{a}}$ & ND & ND & ND & ND & ND & ND & ND & $0.36^{\mathrm{a}}$ & ND & ND & ND & $0.40^{\mathrm{b}}$ & $0.37^{\mathrm{a}}$ \\
\hline
\end{tabular}

Different letters in the same row denote a significant difference according to Tukey's test, $\mathrm{p}<0.05$. 
Chin, Ahmad \& Akowuah (2014) who obtained TPC concentrations of $0.27 \mathrm{mg} \mathrm{GAE} / \mathrm{g}$ in aqueous methanol and $0.33 \mathrm{mg} \mathrm{GAE} / \mathrm{g}$, in methanol. Our results were lower than those reported by Kornsteiner et al. (2006) who found 1.30-4.56 mg GAE/g and Milbury, Chen, and Dolnikowski (2006) who obtained 1.26$2.41 \mathrm{mg} \mathrm{GAE} / \mathrm{g}$. The differences in polyphenol content that could be found in the literature largely depended on the type of extraction solvent and standards used (Salcedo, López de Mishima, \& Nazareno, 2010).

The results obtained for RSA were similar to those for TPC. Concentrations ranged from $0.81 \mathrm{mmol} \mathrm{TE} / \mathrm{kg}$ (Marcona) to $24.2 \mathrm{mmol} \mathrm{TE} / \mathrm{kg}$ (18/03). Kiat et al. (2014) reported higher RSA in methanol extracts compared with $50 \%$ aqueous methanol extracts.

A total of 28 polyphenols were determined, nine phenolic acids and 19 flavonoids. Catechin predominated, averaging $46.3 \%$ of the total, followed by chlorogenic acid, naringenin, rutin, apigenin and astragalin. Our results are consistent with the findings of Yildirim, San, Koyuncu, and Yildirim (2010). On the other hand, Mazinani et al. (2012) found the main phenolic compound to be kampferol (solvent - acetone). Milbury et al. (2006) found no $p$-hydroxybenzoic acid and kaempferol in eight of the most commonly-grown California almonds, while Yildirim et al. (2010) in almond genotypes selected in Isparta province also isolated gallic acid and quercetin. Those differences are probably due to genetic differences, environmental conditions and different methods of quantification. Large differences in phenolic profile among genotypes were identified. Generally, fourteen phenolic compounds were present in all almond genotypes though there were differences in relative levels. Galangin was the rarest polyphenol found in six samples. The content of catechin ranged from 2.67 (Marcona) to $80.75 \mathrm{mg} / \mathrm{kg}$ (25/03). Ellagic acid was found in 13 samples, ranging from $0.02-1.35 \mathrm{mg} / \mathrm{kg}$. Contrary to Yildirim, Yildirim, Şan, Polat, and Sesli (2016) gallic acid was not found in our samples. Rutin varied from 0.611 (4/03) to $11.33 \mathrm{mg} / \mathrm{kg}$ (3/03), and was not found in Troito and 23/03. The lowest content of apigenin $(0.1 \mathrm{mg} / \mathrm{kg})$ was found in Marcona, while it was 100 -fold higher in sample $23 / 03(10.47 \mathrm{mg} / \mathrm{kg})$.

To our best knowledge flavonoids chrysin, pinocembrin, galangin were quantified and reported herein for the first time. This stands also for luteolin and phloretin, as well as for their corresponding glycosides, cynaroside and phlorizin. Significance of flavonoids on human health is well documented so far (Yao et al., 2004).

\subsection{Principal component analysis}

PCA was performed to establish which components could be responsible for differentiation of genotypes and to identify the most promising genotypes to be included in breeding programs or to be recommended for production. The initial matrix of 23 (the number of samples) $\times 47$ (TPC, RSA, oil content, fatty acids and phenolics) was processed using the covariance matrix with auto scaling. The PCA resulted in a nine-component model that explained $83.47 \%$ of the total variance. The first principal component accounted for $23.67 \%$ and the second $12.30 \%$ of the total variance. Although no clear clustering on the PCA correlation plot is visible, some conclusions regarding chemical composition could be identified from Fig. 1(A) while the most influential variables were identified using the loading plots Fig. 1(B). The score plot revealed one sample to be an outlier (3/03), lying outside the Hotelling T2 ellipse due to the highest oil content, methyl ester of linoleic acid and lignoceric acid, rutin, hyperoside, and naringin, sinapic acid, astragalin and kaempferol compared with the other almond genotypes. We have already stated that selection 3/03 was the only almond sample characterized by a soft shell.

Not an outlier, but fully separated on the Fig. $1 \mathrm{~A}$ is genotype 23/03 (the only one with extremely early harvest time and intermediate intensity of kernel color) that was distinguished by the highest level of cis-10-heptadecenoic acid, cis-11-eicosenoic acid, ferullic acid, phlorizin, apigenin, naringenin and pinocembrin.

A small group which was composed of three genotypes $10 / 03$, 25/03 and ZD 2, stored high level of vanillic acid, coniferyl aldehyde, hyperoside and astragalin. Variables for grouping of selections $1 / 03,4 / 03,13 / 03,14 / 03,15 / 03,18 / 03$, and 27/03 were polyphenols with positive values on PC2, cynaroside, phlorizin and $p$-coumaric acid being the most influential (Table 3 ).

The biggest group comprised standard cultivars Marcona, Troito, and Texas, and selections 11/03, 12/03, 16/03, 19/03, $24 / 03,28 / 03,1 / 05$ and ZD1, which were characterized with higher percentages of oleic acid, pentadecanoic acid, and palmitoleic acid (Table 2). Also, those genotypes accumulated very low levels of caffeic acid, phloretin and aesculin, and almost none cynaroside.

In previous PCA applications to almond research Yildirim et al. (2016) reported the relevance of catechin, caffeic acid, epicatechin, and $p$-coumaric acid as discriminant parameters to differentiate almond varieties. Our results partly support those findings.
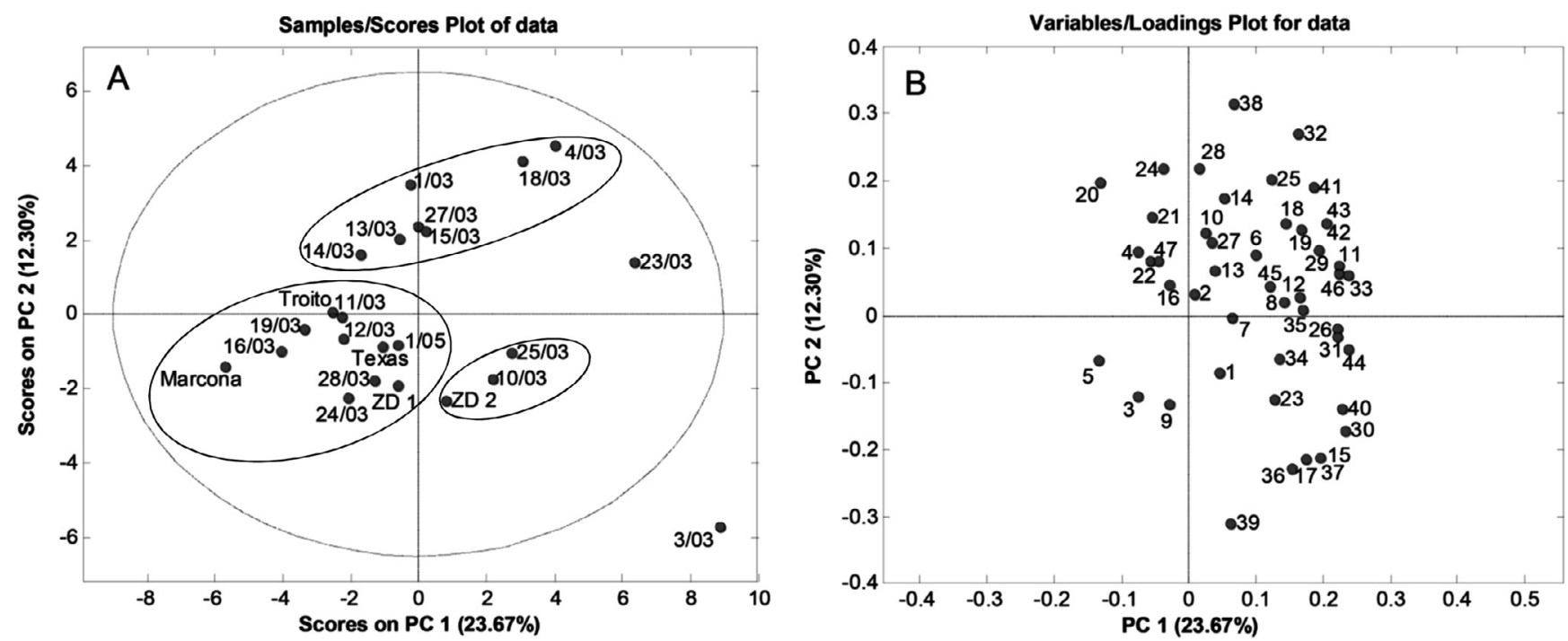

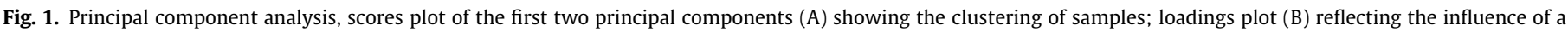
particular parameter. An ellipse represents the 95\% confidence interval using Hotelling's T2 statistics. 


\section{Conclusions}

This study represents a first analysis of fatty acid and phenolic profile of almond grown in Serbia. This collection revealed a high level of diversity among almond selections and cultivars of different geographical origin growing under the same climatic conditions.

This investigation has shown that almonds from Serbia are a good source of phenolics, mainly catechin followed by rutin, naringenin, astragalin, apigenin, and chlorogenic acid. Taking health promoting compounds into consideration selections 16/03, 1/05 and $12 / 03$ were characterized with the highest levels of unsaturated fatty acids. Finally, selection 18/03 was distinguished by the highest TPC and RSA. Knowing that these assays are nonselective and that could provide some information on synergistic effects and other non-phenolic substances that may contribute to the antioxidant activity, selection $18 / 03$ could be recommended for commercialization or use to introduce new genes or alleles into newly-created cultivars.

The present results demonstrate the importance of maintaining and characterizing the genetic diversity of almond in a gene bank collection for further utilization, mainly for identifying interesting parents to be included in a breeding program as a response to new selection objectives, such as improving the chemical quality of the almond kernel. Our findings may assist breeders to improve the quality of almonds to be grown in Serbian or similar agroecological conditions for producing food with a high content of bioactive compounds.

Finally, this study demonstrated that it is possible to grow almond in Northern Serbia with chemical characteristics similar to those of standard cultivars.

\section{Acknowledgements}

The authors gratefully acknowledge the financial support of the Ministry of Education, Science and Technological Development of the Republic of Serbia for this research, as part of the projects TR 31063 and OI 172017. Also, we would like to thank Dr Steve Quarrie (Newcastle University Business School) for proofreading of the manuscript.

\section{Appendix A. Supplementary data}

Supplementary data associated with this article can be found, in the online version, at http://dx.doi.org/10.1016/j.foodchem.2017. 05.006 .

\section{References}

Alasalvar, C., Shahidi, F., \& Amaral, J. S. (2009). Compositional characteristics and health effects of hazelnut (Corylus avellana L.): An overview. In C. Alasalvar \& F. Shahidi (Eds.), Tree Nuts: Composition, phytochemicals, and health effects (pp. 185-214). Boca Raton, FL: CRC Press, Taylor \& Francis Group.

Amarowicz, R., Troszynska, A., \& Shahidi, F. (2005). Antioxidant activity of almond seed extract and its fractions. Journal of Food Lipids, 12, 344-358.

AOAC (1995). Official methods of analysis of the Association of Official Analytical Chemists (method 920.39 C). Arlington: A.O.A.C., 10-12.

Arráez-Román, D., Fu, S., Sawalha, S. M., Segura-Carretero, A., \& FernándezGutiérrez, A. (2010). HPLC/CE-ESI-TOF-MS methods for the characterization of polyphenols in almond skin extracts. Electrophiresis, 31, 2289.

Askin, M. A., Balta, M. F., Twekinas, F. E., Kazankaya, A., \& Balta, F. (2007). Fatty acid composition affected by kernel weight in almond [Prunus dulcis (Mill.) D.A. Webb] genetic resources. Journal of Food Composition and Analysis, 20, 7-12.

Balta, F., Battal, P., Balta, M. F., \& Yoruk, H. I. (2009). Free sugar compositions based on kernel taste in almond genotypes Prunus dulcis from eastern Turkey. Chemistry of Natural Compounds, 45, 221-224.

Barreira, J. C., Ferreira, I. C., Oliveira, M. B., \& Pereira, J. A. (2008). Antioxidant activity and bioactive compounds of 10 Portuguese regional and commercial almond cultivars. Food and Chemical Toxicology, 46, 2230-2235.

Beyhan, Ö., Aktas, M., Yilmaz, N., Simsek, N., \& Gerçekçioğlu, R. (2011). Determination of fatty acid compositions of some important almond (Prunus amygdalus L.) varieties selected from Tokat province and Eagean region of Turkey. Journal of Medicinal Plants Research, 5, 4907-4911.

Blomhoff, R., Carlsen, M. H., Andersen, L. F., \& Jacobs, D. R. Jr., (2006). Health benefits of nuts: potential role of antioxidants. British Journal of Nutrition, 96, S52-S60.

Bolling, B. W. Dolnikowski, G. \& Blumberg J. B. (2009). Quantification of almond skin polyphenols by liquid chromatography-mass spectrometry. Journal of Food Science, 74, C326-C332.

Čolić, S., Rakonjac, V., Zec, G., Nikolić, D., \& Fotirić Akšić, M. (2012). Morphological and biochemical evaluation of selected almond [Prunus dulcis (Mill.) D.A.Webb] genotypes in northern Serbia. Turkish Journal of Agriculture and Forestry, 36 429-438.

Čolić, S., Milatović, D. Nikolić, D., \& Zec, G. (2010). Isoenzyme polymorphism of almond genotypes selected in the region of northern Serbia. Horticultural Science, 37, 56-61.

EN ISO 5508:1995 Animal and vegetable fats and oils-Analysis by gas chromatography of methyl esters of fatty acids)

Gülcan, R. (1985). Descriptor list for almond (prunus amygdalus) revised. Rome: IBPGR Secretariat.

ISO 12966-2:2012 Animal and vegetable fats and oils - Gas chromatography of fatty acid methyl esters - Part 2: Preparation of methyl esters of fatty acids.

Kiat, V. V., Siang, W. K., Madhavan, P., Chin, J. H., Ahmad, M., \& Akowuah, G. A. (2014). FT-IR profile and antiradical activity of dehulled kernels of apricot, almond and pumpkin. Research Journal of Pharmaceutical, Biological and Chemical Sciences, 5, 112-120.

Kodad, O., \& Socias i Company, R. (2008). Variability of oil content and of major fatty acid composition in almond (Prunus amygdalus Batsch) and its relationship with kernel quality. Journal of Agricultural and Food Chemistry, 56, 4096-4101.

Kodad, O., Estopanán, G., Juan, T., Alonso, J. M., Espiau, M. T., \& Socias i Company, R. (2014). Oil content, fatty acid composition and tocopherol concentration in the Spanish almond genebank collection. Scientia Horticulturae, 177, 99-107.

Kornsteiner, M., Wagner, K. H., \& Elmadfa, I. (2006). Tocopherols and total phenolics in 10 different nut types. Food Chemistry, 98, 381-387.

Magnusson B. \& Ornemark U. (eds.) Eurachem Guide: The Fitnessfor Purpose of Analytical Methods - A Laboratory Guide to Method Validation and Related Topics, (2nd ed. 2014).

Mazinani, S., Hossein, A., Rad, E., \& Khaneghah, A. M. (2012). Determination and comparison the amount of toccopherolic and phenolic compounds and fatty acids profile in edible nuts (pistachio, almond and walnut) oil. Advances in Environmental Biology, 6, 1610-1619.

Milbury, P. E., Chen, C. Y., \& Dolnikowski, G. G. (2006). Determination of flavonoids and phenolics and their distribution in almonds. Journal of Agricultural and Food Chemistry, 54, 5027-5033.

Miraliakbari, H., \& Shahidi, F. (2008). Lipid class compositions, tocopherols and sterols of tree nut oils extracted with different solvents. Journal of Food Lipids, 15, 81-96.

Monagas, M., Garrido, I., Lebrón-Aguilar, R., Bartolome, B., \& Gómez-Cordovés, C. (2007). Almond (Prunus dulcis (Mill.) D.A. Webb) skins as a potential source of bioactive polyphenols. Journal of Agricultural and Food Chemistry, 55, 8498-8507.

Natić, M., Dabić, D., Papetti, A., Fotirić Akšić, M., Ognjanov, V., Ljubojević, M., \& Tešić Ž. (2015). Analysis and characterisation of phytochemicals in mulberry (Morus alba L.) fruits grown in Vojvodina, North Serbia. Food Chemistry, 171, 128-136.

Özcan, M. M., Ünver, A., Erkan, E., \& Arslan, D. (2011). Characteristics of some almond kernel and oils. Scientia Horticulturae, 127, 330-333.

Pavlović, A., Dabić, D., Momirović, M., Dojčinović, B., Milojković-Opsenica, D., Tešić, Ž., \& Natić, M. M. (2013). Chemical composition of two different extracts of berries harvested in Serbia. Journal of Agricultural and Food Chemistry, 61, 4188-4194.

Salas-Salvadó, J., Bulló, M., Pérez-Heras, A., \& Ros, E. (2006). Dietary fibre, nuts and cardiovascular disease. British Journal of Nutrition, 96, S45-S51.

Salcedo, C. L., López de Mishima, B. A., \& Nazareno, M. A. (2010). Walnuts and almonds as model systems of foods constituted by oxidisable, pro-oxidant and antioxidant factors. Food Research International, 43, 1187-1197.

Segura, R., Casimiro, J., Lizarraga, A., \& Ros, E. (2006). Other relevant components of nuts: phytosterols, folate and minerals. British Journal of Nutrition, 96, S36-S44.

Socias i Company, R., Alonso, J. M., Kodad, O., \& Gradziel, T. M. (2012). Almond. In M L. Badenes \& D. Byrne (Eds.). Fruit Breeding, Handbook of Plant Breeding (8 pp. 697-728). New York: Springer-Verlag.

Vinson, J. A., \& Cai, Y. (2012). Nuts, especially walnuts, have both antioxidant quantity and efficacy and exhibit significant potential health benefits. Food $\mathcal{E}$ Function, 3, 134-140.

Wijeratne, S. S. K., Amarowicz, R., \& Shahidi, F. (2006). Antioxidant activity of almonds and their by-products in food model systems. Journal of American Oil Chemists' Society, 83, 223-230.

Xie, L. \& Bolling, B. W. (2014). Characterisation of stilbenes in California almonds (Prunus dulcis) by UHPLC-MS. Food Chemistry, 148, 300-306.

Yada, S., Lapsley, K., \& Huang, G. (2011). A review of composition studies of cultivated almonds: Macronutrients and micronutrients. Journal of Food Composition and Analysis, 24, 469-480.

Yao, L. H., Jiang, Y. M., Shi, J., Tomás-Barberán, F. A., Datta, N., Singanusong, R., \& Chen, S. S. (2004). Flavonoids in food and their health benefits. Plant Foods and Human Nutrition, 59, 113-122.

Yildirim, A. N., San, B., Koyuncu, F., \& Yildirim, F. (2010). Variability of phenolics, $\alpha$ tocopherol and amygdalin contents of selected almond (Prunus amygdalus Batsch.) genotypes. International Journal of Food Agriculture and Environment, 8 76-79. 
Yildirim, A. N., Yildirim, F., Şan, B., Polat, M., \& Sesli, Y. (2016). Variability of phenolic composition and tocopherol content of some commercial Almond cultivars. Journal of Applied Botany and Food Quality, 89, 163-170.

Zacheo, G., Cappello, M. S., Gallo, A., Santino, A., \& Cappello, A. R. (2000). Changes associated with post-harvest ageing in almond seeds. LWT Food Science and Technology, 33(6), 415-423.
Zhu, Y., Wilkinson, K. L., \& Wirthensohn, M. G. (2015). Lipophilic antioxidant content of almonds (Prunus dulcis). A regional and varietal study. Journal of Food Composition and Analysis, 39, 120-127. 